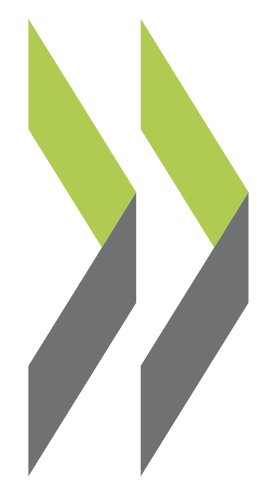

OECD Economics Department Working Papers No. 980

\author{
Import Competition, \\ Domestic Regulation
} and Firm-Level Productivity Growth in the OECD

\section{Sarra Ben Yahmed,}

Sean Dougherty 
Organisation de Coopération et de Développement Économiques

Organisation for Economic Co-operation and Development

03-Sep-2012

ECONOMICS DEPARTMENT

English - Or. English

IMPORT COMPETITION, DOMESTIC REGULATION AND FIRM-LEVEL PRODUCTIVITY GROWTH IN THE OECD

ECONOMICS DEPARTMENT WORKING PAPER No. 980

by Sarra Ben Yahmed and Sean Dougherty

Complete document available in pdfformat only.

All Economics Department Working papers are available through OECD's Internet website at www.oecd.org/eco/workingpapers

JT03325741

Complete document available on OLIS in its original format

This document and any map included herein are without prejudice to the status of or sovereignty over any territory, to the delimitation of international frontiers and boundaries and to the name of any territory, city or area. 


\section{ABSTRACT/RÉSUMÉ}

Import competition, domestic regulation and firm-level productivity growth in the OECD

This paper examines how import penetration affects firms' productivity growth taking into account the heterogeneity in firms' distance to the efficiency frontier and country differences in product market regulation. Using firm-level data for a large number of OECD countries, the analysis reveals non-linear effects of both sectoral import penetration and de jure product market regulation measures depending on firms' positions along the global distribution of productivity levels. The heterogeneous effects of international competition and domestic product market regulation on firm-level productivity growth are consistent with a neo-Schumpeterian view of trade and regulation. Close to the technology frontier, import competition has a strongly positive effect on firm-level productivity growth, with stringent domestic regulation reducing this effect substantially. However, far from the frontier, neither import competition nor its interaction with domestic regulation has a statistically significant effect on firm-level productivity growth. The results suggest that insufficient attention has been made in the trade literature to within-firm productivity growth.

JEL classification codes: F1; K2; L2; L5; O1

Keywords: Firm productivity growth; behind-the-border regulatory barriers; product market regulation; import competition; international trade

$* * * * * * * * * * * *$

\section{Concurrence des importations, réglementation interne et croissance de la productivité au niveau de l'entreprise dans les pays de l'OCDE}

Ce document explore les effets des importations sur la croissance de la productivité des entreprises, tout en tenant compte des différences de positionnement des entreprises par rapport à leur frontière technologique et des différences de réglementation des marchés des biens entre les pays. En utilisant des données de firmes pour un grand nombre de pays de l'OCDE, l'analyse fait apparaître des effets non linéaires des importations ainsi que des dispositions légales concernant les marchés des biens sur la croissance de la productivité des entreprises. Ce résultat est conforme à une conception néo-Schumpétérienne des effets des échanges et de la réglementation sur la productivité. Pour les entreprises proches de la frontière technologique, la concurrence étrangère a un effet fortement positif sur la croissance de la productivité, tandis qu'une réglementation interne stricte réduit sensiblement cet effet. En revanche, pour les entreprises loin de la frontière technologique, ni la concurrence étrangère ni son interaction avec la réglementation nationale n'ont d'effet statistiquement significatif sur la croissance de la productivité. Les résultats obtenus montrent que les analyses désagrégées, au niveau de la firme, sont un terrain prometteur pour la littérature qui a été jusque là davantage centrée sur les réallocations et la croissance au niveau sectoriel.

Codes JEL : F1 ; K2 ; L2 ; L5 ; O1

Mots clés : Croissance de la productivité des entreprises ; réglementation nationale des marchés des biens ; concurrence étrangère ; échanges internationaux

(C) OECD (2012)

You can copy, download or print OECD content for your own use, and you can include excerpts from OECD publications, databases and multimedia products in your own documents, presentations, blogs, websites and teaching materials, provided that suitable acknowledgment of OECD as source and copyright owner is given. All requests for commercial use and translation rights should be submitted to rights@oecd.org. 


\title{
IMPORT COMPETITION, DOMESTIC REGULATION AND FIRM-LEVEL PRODUCTIVITY GROWTH IN THE OECD
}

\author{
Sarra BEN YAHMED and Sean DOUGHERTY*
}

\section{Introduction}

Globalisation has dramatically reduced explicit barriers to international trade in OECD as well as non-OECD countries over recent decades. These tariff-type barriers have fallen far enough in manufacturing that they likely no longer represent a major obstacle to goods exporting and importing (Bouët et al., 2008). Institutional limits on protection that prevent countries from raising tariffs even in times of economic crisis have so far proven effective in preventing a bout of defensive, or retaliatory, anti-trade measures, even in the context of the panic-inducing Great Recession that we have just experienced (OECD, 2011).

Nevertheless, behind-the-border regulation still remains quite stringent in many economies (Wölfl et al., 2009; Conway et al., 2010). Stringent regulation of product markets obstructs firm entry, operation and exit, thereby limiting competition, which can reduce firms' ability and incentives to improve their productivity. However, the mechanisms that cause weak competition to hamper productivity are not fully understood. In their recent review of endogenous growth theory, Aghion and Howitt (2009) argue that there is a U-shaped relationship between the degree of competition and productivity, where firms closer to the frontier face stronger incentives to innovate in order to overcome the potential threat of new entrants. Near the frontier, stringent regulation reduces neck-to-neck competition and innovation, harming firm productivity. In contrast, farther from the frontier, Schumpeter (Mark II)-type effects dominate and firms face discouragement, making innovation and productivity growth less likely, regardless of regulation.

New trade theory also incorporates heterogeneity in firm technological efficiency, though with a different perspective, as most theoretical papers take firms' productivity levels as given and

\footnotetext{
* Sean Dougherty is Senior Economist in the OECD Economics Department. Sarra Ben Yahmed is a PhD candidate at Université Aix-Marseille (GREQAM). An earlier version of this paper was circulated under the title "Trade, Regulation and Firm-Level Productivity in the OECD." Useful feedback was received in presentations at the Banque de France, DEFI (Aix-en-Provence), the OECD Economics Department, and the Paris School of Economics. The authors would also like to thank Philippe Aghion, Jens Arnold, Andrea Bassanini, Romain Duval, Lionel Fontagné, Giuseppe Nicoletti, Joaquim Oliveira Martins, Gianmarco Ottaviano, Jean-Luc Schneider and Cyrille Schwellnus for useful comments and suggestions. This paper was written under the personal capacity of the authors and does not necessarily reflect the views of the OECD nor its member countries.
} 
investigate how sectoral productivity changes in the aftermath of trade liberalization. Various models featuring heterogeneous firms, notably Melitz's (2003), posit that trade liberalization yields entry and exit dynamics that reallocate market shares from low-productivity firms to higher productivity firms that compete in international markets. Bernard et al. (2007) show how this process can help strengthen comparative advantage through creative destruction, though in neither case do the dynamics come about through intra-firm productivity dynamics. Melitz and Ottaviano (2008) highlight the pro-competitive effect of trade taking into account market size. They show that sectoral productivity can be enhanced through increasing toughness of import competition, implying the potential for dynamic gains from policy reform.

This paper builds on the intuition of new trade models on the pro-competitive effect of trade along with the prediction of endogenous growth models where the effect of competition and regulation on firm productivity depends on firms' efficiency levels. It takes a differences-indifferences approach that uses the insights from the new trade literature to identify the empirical effects of import competition and anti-competitive domestic regulation on productivity at the firm level, also incorporating distance-to-frontier effects. In so doing, it develops new evidence in support of both sets of theories, suggesting that $(i)$ trade models could be enriched by incorporating a distance-to-frontier and intra-firm productivity dimension, and (ii) distance-tofrontier ideas could be further enriched by examining their interactions with trade.

Beyond these general insights, several important findings stand out:

- Stronger competition, in the form of higher import penetration, is associated with higher firm-level productivity growth close to the productivity frontier, an effect that remains robust even when estimated in lags, though it varies when the smallest firms are oversampled in the dataset. The main result is consistent with the predictions of the Aghion endogenous growth model as well as the Melitz and Ottaviano (2008) framework, though the latter would not have predicted a differential firm-level effect vis-à-vis the technology frontier.

- Close to the technology frontier, anti-competitive product market regulation substantially reduces the scope for TFP improvements spurred by import competition; far from the frontier, the interaction between regulation and foreign competition is not statistically significant. The effect of product market regulation depends on the sectoral trade orientation; more precisely, we find that product market regulation damages the scope for 
productivity growth at least in part by reducing the competition-enhancing effect of import competition on top firms.

- The productivity-enhancing effect of import competition and the mitigating effect of product market regulation are robust to the inclusion of a Herfindahl index that captures the market shares concentration across firms, controls for the stringency of upstream regulation, as well as country-time fixed effects and industry fixed effects that capture respectively country specific policies or macroeconomic shocks and time-invariant industryspecific characteristics such as the intensity of ICT use.

In order to examine these questions, a large-scale firm database (Amadeus) is examined that covers half of the OECD member countries, which is then re-weighted to be representative of the actual size distribution of firms in the whole population, and matched with regulation and trade datasets. This firm data is sufficient to allow for the measurement of robust productivity measures that take account of potential simultaneity biases. Unique OECD indexes of product market regulation are used to measure de jure regulatory settings, at the country level and across time. International trade data are matched with production data, to generate measures of import penetration at the detailed industry level.

Previous evidence on the effect of domestic regulation on productivity has examined various channels, though these studies have generally not examined their interaction with trade. A number of empirical studies, particularly those of the $\operatorname{OECD}(2003,2006,2011)$, have found distortionary effects of indicators of product and labour market regulation on overall productivity outcomes. For instance, Arnold et al. (2010) look at the effect of product market regulation on firm-level productivity - through the ICT channel - and find supportive evidence of distanceto-frontier effects. At the industry level, Bourlès et al. (2010) look at the effect of upstream product market regulation on sector-level productivity, and they also find distance-to-frontier effects. Conway et al. (2006) found similar sectoral effects for broader market regulation, while Nicoletti and Scarpetta (2003) found related, yet inverted, effects with respect to the distance-to-frontier.

More aggregate empirical work has used less detailed indicators of institutional and policy settings to examine the role of institutions in mediating the role of trade in affecting overall growth and productivity outcomes. Cross-country studies include Dollar and Kraay (2003), Rodrick et al. (2004), Alcalá and Ciccone (2004), and Freund and Bolaky (2008), who have 
tried to disentangle the respective roles of institutions and trade for growth at the country level. On balance, the evidence appears to suggest that institutions have a more fundamental role, as they complement trade liberalisation, and strengthen the long term effects of trade on growth, by enhancing the role of comparative advantage. However, the types of policies and reforms that may drive productivity in this context are still not clear from this literature 1

Research at the level of the firm seems more promising to reveal the underlying mechanics of how policies may work through trade to affect productivity and growth outcomes. Firm-level analysis has revealed a substantial role for product market regulation in affecting the margins of firm exit and entry as well as reallocation of productivity across firms fs(e.g. Bartelsman et al., 2009). However, this work does not explicitly consider how international trade may drive and/or reinforce these margins.

There have been a series of country-specific firm-level studies that have identified substantial roles for international trade regulation specifically in affecting firm entry/exit and reallocative margins, for Chile (Pavnick, 2002; Bas and Ledezma, 2009), Columbia (Fernandez, 2007), France (Bas and Strauss-Kahn, 2011), India (Topalova, 2004; Goldberg et al., 2010), Indonesia (Amiti and Konings, 2007) and the UK (Aghion et al., 2009). Several of these studies show that reductions in import barriers can help to boost within-firm productivity (Amiti and Konings, 2007; Bas and Ledezma, 2009; Goldberg et al., 2010). However, these single-country studies do not address behind-the-border regulation, which varies principally across countries.

The paper proceeds as follows. The second section describes the data and sampling frame, the construction of productivity, import penetration and domestic regulation measures. The third section motivates the empirical approach, and examines the effects of import penetration and domestic regulation on firm-level productivity growth. The fourth section concludes.

\section{Data and measurement}

In order to investigate the questions raised above, firm-level data are used to compute productivity measures, sectoral trade data are used to measure foreign competition, and restrictive regulation is measured using the OECD's economy-wide indexes of product market regulation.

\footnotetext{
${ }^{1}$ One promising approach from a related literature uses incomplete contract theory to examine the effect of overall institutional quality on the organization of trade. Studies following this approach include Acemoglu, Antràs and Helpman (2007), who find an important role of contracting institutions leading to strengthened comparative advantage.
} 


\subsection{Firm-level data: Amadeus}

Firm level data are used based on company reports included in the Amadeus database compiled by the Bureau van Dijk. This database covers European OECD countries over the time period 1995-2005. The countries with sufficient numbers of firms for our use are Belgium, the Czech Republic, Denmark, Finland, France, Germany, Italy, the Netherlands, Norway, Poland, Portugal, Spain, Sweden and the United Kingdom. The data for Greece are not used since they lack wage and materials data. While all the countries included are OECD members, the former transition economies of Central and Eastern Europe are likely to have a wider dispersion of productivity across firms than the other countries as a result of their one-time structural transitions.

Data are cleaned for potential outliers that we identify by several criteria. First, firms with negative values for any variable entering the production function - operating revenue or value added, wages, capital stock, material inputs - or with depreciation higher than net capital stock are eliminated from the sample. Firms that report extreme year-to-year variation in ratios between production function variables and extreme reversals in one of these variables are not retained, either. Finally, outliers have been removed by eliminating the top and bottom one percent of the productivity distribution and subsequently re-estimating productivity without these extreme observations. The productivity estimation is described in more detail below.

Sectoral coverage includes all tradable goods and services, including mining, all of manufacturing (ISIC 15 to 37), electricity, utilities (ISIC 40, 51, 52), transport and communications (ISIC 60 to 64), business activities as R\&D, advertising (ISIC 71 to 74 ) and recreational and cultural activities (ISIC 92). Consolidated accounts in the Amadeus dataset are dropped, which avoids problems of double-counting.

\subsection{Sampling frame}

The Amadeus data are broadly representative of the business sectors of OECD countries, since they include virtually all public companies, and as such are a fair representation of larger companies. However, smaller firms are underrepresented, since they typically do not report balance sheet information publicly. In addition, not all firms in the Amadeus data report information on all production function variables. The remaining sample used in this study includes only firms for which TFP estimates could be obtained. 
In order to ensure that the sample of firms is as representative as possible of the population distribution of firms across size classes, sectors and countries, a re-sampling procedure was applied (see Schwellnus and Arnold, 2008). First, population weights for every size-sectorcountry strata were calculated from the OECD Structural Business Statistics database for the year 2000. Second, random draws with replacement from each size-sector-country strata in the TFP sample were taken until the weight of each strata corresponds to its population weight 2

This method resulted in a sample that is representative of the population distribution along the dimensions of employment size, sector and country. The sample size is then set to 139065 firms (drawn from a set of 79513 real firms) which results in 831187 firm-year observations. While this method yields a more representative sample in the year 2000, it may also increase measurement error since 'successful' smaller firms are over-sampled. As a result, the resampled dataset may be less representative as the time period shifts away from the year 2000 since normally such firms have high rates of entry and exit. Thus, both the non-resampled and the resampled data are considered in the basic specifications in order to ensure robustness.

\subsection{Estimation of Total Factor Productivity}

Our productivity variable, total factor productivity (TFP), measures the firm-level efficiency in the use of all inputs. We calculate TFP as the residual from the estimation of a logarithmic Cobb-Douglas production function of the form:

$$
\ln Y_{i s c t}=\alpha_{s c} \ln l_{i s c t}+\beta_{s c} \ln k_{i s c t}+\epsilon_{i s c t}
$$

where the subscripts stand for the firm $i$ from country $c$ operating in sector $s$ at time $t$. The dependent variable of the production function is the firm's value-added $(y)$. The production factors are labour $(l)$ and capital $(k)$. When value-added was not available, it was imputed as the residual between operating revenue and material inputs. Labour inputs are measured using the total wage bill, while net capital stocks were used to measure capital input. Nominal values are deflated using sector-specific price indexes, with the exception of capital stocks that have been deflated using deflators for gross fixed capital formation. The production function is estimated at the sector-country level $s c$, in order to avoid strong assumptions on the homogeneity of production technologies across sectors and OECD countries. The residuals $\epsilon_{\text {isct }}$ represent plant-

\footnotetext{
${ }^{2}$ The re-sampling procedure is restricted to firms with at least 20 employees since the coverage below this threshold is unsatisfactory.
} 
specific efficiency in the year $t$.

The ideal measure of TFP would be in volume terms, "physical TFP". However, given the available data, we use a "revenue-based TFP". The plusses and minuses of using various measures are discussed in Foster, Haltiwanger and Syverson (2008). In most business micro data sets like Amadeus, establishment-level prices are unobserved. Thus, establishment output is measured as revenue divided by a common industry-level deflator. This method embodies within-industry price differences in output and productivity measures. Difficulties arise when prices reflect idiosyncratic demand shifts, demographic characteristics or market power variation rather than differences in quality or production efficiency. For instance, a firm sheltered from competition because of some regulatory barriers may set high prices and according to a "revenuebased TFP" it may look more efficient than a firm in a more deregulated environment even if their efficiency levels are similar. Since we cannot implement the Foster et al. (2008) treatment, firm fixed effects are used to control for time invariant characteristics that may determine firmlevel prices.

We now turn to the endogeneity issue. Estimation of Equation 1 by OLS can lead to biased estimates as inputs in the production function are likely to be related to the residuals. Let us decompose the residuals as follows:

$$
\epsilon_{i s c t}=\omega_{i s c t}+u_{i s c t}
$$

Equation 2 decomposes firm efficiency into a part that is predictable by the firm $\omega_{\text {isct }}$, though not observable in the data, and a part due to productivity shock that can be forecast nor by the firm nor by the econometrician.

Firms choose their input on the basis of their knowledge of their environment and own efficiency $\omega_{\text {isct }}$. Hence, if firms that anticipate high efficiency level hire more workers and invest more, OLS estimates will be biased upward. The endogeneity of input choices is well known in the literature. Consistent productivity estimates are obtained using the semi-parametric estimation techniques of Olley and Pakes (1996) or Levinsohn and Petrin (2003). These methods correct for simultaneity biases. To carry out such estimations, we need data on investment for the former and intermediate inputs for the latter in order to proxy firm's private knowledge of its efficiency.

Our preferred TFP estimates are those from the Levinsohn and Petrin (LP) method, which 
uses information on materials to correct for simultaneity biases. We do not use the Olley and Pakes technique, as their method requires primary information on investment to proxy for unobserved productivity shocks, while prior information on investment is not provided in Amadeus. Although we could create an investment measure using the perpetual inventory equation, we do not follow this path because of a high probability of measurement errors in capital depreciation.

Hence, we compute firm TFP by using intermediate inputs $m$ to capture variation in firms' prediction of their efficiency $\omega$.

$$
\omega_{i s c t}=f\left(m_{i s c t}, k_{i s c t}\right)
$$

Introducing this function into Equation 1, we now have:

$$
\ln Y_{i s c t}=\alpha_{s c} \ln l_{i s c t}+\beta_{s c} \ln k_{i s c t}+f\left(m_{i s c t}, k_{i s c t}\right)+u_{i s c t}
$$

The variation in inputs is now not related with the error term $u_{\text {isct }}$ so that we have consistent estimates of the parameters. We compute firm TFP as the residual from an estimate of Equation 3. At this stage, firms' TFP values are not yet comparable across sectors and countries.

Following Pavcnik (2002) and Fernandez (2007), we construct a TFP index to deal with the comparability issue. The TFP index is based on the LP estimates and is constructed in two steps. First, for each 4-digit sector $s$ and country $c$, we construct a reference hypothetical plant that has mean output and input levels calculated over the whole period. We compute the TFP of this reference plant as

$$
\widehat{A}_{s c}^{r e f}=\bar{Y}_{s c}-\widehat{\alpha}_{s c} \bar{L}_{s c}-\widehat{\beta}_{s c} \bar{K}_{s c}
$$

where $\widehat{\alpha}_{s c}$ and $\widehat{\beta}_{s c}$ are the estimates obtained from the regression estimate of Equation 3.

Second, we obtain plant $i$ 's productivity index at time $t$ by subtracting the reference plant productivity $A^{\text {ref }}$ from plant $i$ 's productivity as estimated in Equation 3.

$$
A_{i s c t}=Y_{i s c t}-\widehat{\alpha}_{s c} L_{i s c t}-\widehat{\beta}_{s c} K_{i s c t}-\widehat{A}_{s c}^{r e f}
$$

This index number methodology follows Aw, Chen and Roberts (2001) and Caves, Christensen and Tretheway (1981). The relative TFP measure obtained ensures comparability across 
industries and countries.

We then compute firm TFP growth rates as the $\log$ difference: $\Delta A_{\text {isct }}=\ln A_{\text {isct }}-\ln A_{\text {isct-1 }}$. Summary statistics for firm's TFP growth are shown in Table 1. It displays the standard variation, the mean, median, the 10th and 90th percentiles of firm's TFP growth for each country. It shows that there is a wide variation in $\Delta A_{\text {isct }}$ both within and across countries.

Table 1: Summary statistics - Firm TFP growth

\begin{tabular}{lccccc}
\hline \hline & & & & & \\
Country & Standard deviation & 10th percentile & mean & median & 90th percentile \\
\hline All & 2.87 & -1.24 & -.01 & .01 & 1.28 \\
BEL & 4.09 & -1.76 & 0 & 0 & 1.79 \\
CZE & 1.78 & -.84 & .09 & .01 & 1.03 \\
DEU & 10.83 & -1.7 & .41 & 0 & 2.5 \\
DNK & 6.72 & -.72 & .14 & .01 & 1.17 \\
ESP & 2.01 & -1.01 & .01 & 0 & 1.04 \\
FIN & 2.1 & -1.3 & .04 & .01 & 1.46 \\
FRA & 1.2 & -.63 & .06 & .03 & .76 \\
GBR & 4.17 & -1.64 & -.05 & -.02 & 1.53 \\
ITA & 2.3 & -1.55 & .01 & .01 & 1.56 \\
NLD & 3.51 & -1.83 & .14 & 0 & 2.54 \\
NOR & 2.01 & -1.12 & .06 & .04 & 1.35 \\
POL & 4.32 & -1.75 & .47 & .05 & 3.13 \\
PRT & 2.15 & -1.02 & .07 & .01 & 1.36 \\
SWE & 6.43 & -4.16 & -.45 & -.03 & 3.4 \\
\hline Source: Authors' calculations based on Amadeus database. & Not resampled dataset.
\end{tabular}

\subsection{Trade openness}

To capture the pro-competitive impact of trade we construct a proxy for foreign competition which is import penetration. Trade data come from the Comtrade database. By combining it with detailed production data from OECD Structural Demographic Business Statistics (SDBS) database, we compute different openness measures at the 4-digit sectoral level. Import penetration is constructed in the following way for each sector, country and year:

$$
I P_{s c t}=\frac{M_{s c t}}{Q_{s c t}+M_{s c t}-X_{s c t}}
$$

where $M_{s c t}$ is total imports of good $s$ to country $c$ in year $t . Q_{s c t}$ is the production of good $s$ while $X_{\text {sct }}$ is the exports of good $s$ from country $c$ to its trade partners in year $t$.

Summary statistics for the import penetration measure across countries are shown in Table 2. This table displays the median, the 25 th and 75 th percentiles of import penetration. There is considerable variation in import penetration across country and time, and these differences persist even within narrowly defined sectors. 
Table 2: Summary statistics - Import penetration

\begin{tabular}{|c|c|c|c|c|c|c|}
\hline \multirow[b]{2}{*}{ Country } & \multicolumn{3}{|c|}{ 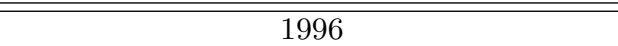 } & \multicolumn{3}{|c|}{2005} \\
\hline & 25th percentile & median & 75th percentile & 25th percentile & median & 75th percentile \\
\hline All & .17 & .43 & .75 & .23 & .55 & .87 \\
\hline BEL & .36 & .7 & 1.26 & .42 & .88 & 1.57 \\
\hline $\mathrm{CZE}$ & .05 & .35 & .61 & .25 & .61 & 1.02 \\
\hline DEU & .02 & .2 & .64 & .2 & .41 & .87 \\
\hline DNK & .32 & .59 & .86 & .4 & .76 & 1.22 \\
\hline ESP & .13 & .29 & .55 & .17 & .46 & .68 \\
\hline FIN & .16 & .47 & .67 & .18 & .49 & .82 \\
\hline FRA & .17 & .37 & .54 & .23 & .48 & .7 \\
\hline GBR & .17 & .4 & .61 & .24 & .54 & .78 \\
\hline GRC & .06 & .26 & .63 & .3 & .58 & .82 \\
\hline ITA & .12 & .22 & .37 & .14 & .31 & .5 \\
\hline NLD & .42 & .96 & 1.41 & .4 & .84 & 1.73 \\
\hline NOR & .36 & .62 & .82 & .3 & .62 & .91 \\
\hline POL & .02 & .25 & .44 & .16 & .55 & .75 \\
\hline PRT & .15 & .41 & .72 & .23 & .49 & .76 \\
\hline SWE & .21 & .51 & .84 & .27 & .55 & .93 \\
\hline
\end{tabular}

Source: Authors' calculations based on Comtrade and OECD SDBS databases.

\subsection{Regulation and market structure measures}

The primary measure of regulation is the OECD product market regulation indicators of de jure anti-competitive regulations, focusing on the vintages which coincide with the coverage of the Amadeus data. These include the 1998 and 2003 data updates, the settings for which are assumed to be unchanged for the immediately following years, preceeding the most recent 2008 data update. These indicators include both domestic as well as international barriers; only the domestic barriers are used here, specifically the grouping 'barriers to entrepreneurship', which covers sub-indicators for administrative burdens on startups, regulatory and administrative opacity and sectoral barriers to competition. Each of the low-level indicators are based on a scoring of regulatory data on a 0 to 6 scale reflecting the extent to which the regulations inhibit competition (see Wölfl et al., 2009; OECD, 2011).

A Herfindahl index of firm concentration at the four-digit level using the Amadeus firm database is used to control for the extent of de facto competition from domestic firms. It is calculated in the standard way, based on the sum of the square revenue market shares of each firm in an industry, so that it ranges between $1 / n$ and 1 where $n$ is the number of firms. The OECD 'Regimpact' measure, which assesses the industry-specific knock-on effects of anticompetitive regulation in seven network sectors is also used in robustness checks to control for the extent of upstream regulation 3

\footnotetext{
${ }^{3}$ These indicators are calculated using a bottom-up approach in which regulatory data are quantified and aggregated to into summary indicators by sector using weights from input-output tables.
} 
Table 3 displays some summary statistics for the main measures of domestic competition. Though there has been convergence in these measures over time, a wide variation is still observed across countries.

Table 3: Summary statistics - Market structure and domestic regulation

\begin{tabular}{lccccc}
\hline \hline \multicolumn{5}{c}{ 'Barriers to entrepreneurship' Index } \\
Country & Standard deviation & 10th percentile & mean & median & 90th percentile \\
\hline All & .6 & 1.45 & 2.23 & 2.39 & 3.05 \\
BEL & .22 & 1.88 & 2.16 & 2.33 & 2.33 \\
CZE & .08 & 2.09 & 2.13 & 2.09 & 2.27 \\
DEU & .24 & 1.83 & 2.05 & 1.83 & 2.31 \\
DNK & .17 & 1.42 & 1.52 & 1.42 & 1.82 \\
ESP & .35 & 1.63 & 2.17 & 2.39 & 2.39 \\
FIN & .49 & 1.42 & 2.01 & 2.41 & 2.41 \\
FRA & .62 & 1.79 & 2.55 & 3.05 & 3.05 \\
GBR & .23 & .95 & 1.29 & 1.45 & 1.45 \\
ITA & .54 & 1.58 & 2.38 & 2.74 & 2.74 \\
NLD & .13 & 1.78 & 1.93 & 2.05 & 2.05 \\
NOR & .21 & 1.33 & 1.45 & 1.33 & 1.83 \\
POL & .28 & 3.15 & 3.42 & 3.15 & 3.72 \\
PRT & .25 & 1.57 & 2.02 & 2.16 & 2.16 \\
SWE & .48 & 1.15 & 1.69 & 2.11 & 2.11 \\
\hline \hline
\end{tabular}

Herfindahl Index

\begin{tabular}{lccccc} 
Country & Standard deviation & 10th percentile & mean & median & 90th percentile \\
\hline All & .08 & 0 & .05 & .02 & .12 \\
BEL & .12 & .01 & .09 & .04 & .23 \\
CZE & .11 & .01 & .09 & .06 & .22 \\
DEU & .2 & .04 & .22 & .16 & .45 \\
DNK & .11 & .02 & .11 & .08 & .21 \\
ESP & .07 & 0 & .03 & .01 & .07 \\
FIN & .13 & .02 & .11 & .06 & .25 \\
FRA & .07 & 0 & .04 & .02 & .1 \\
GBR & .09 & .01 & .08 & .04 & .18 \\
ITA & .06 & 0 & .03 & .01 & .08 \\
NLD & .21 & .05 & .23 & .15 & .53 \\
NOR & .09 & 0 & .05 & .03 & .09 \\
POL & .13 & .02 & .1 & .05 & .25 \\
PRT & .21 & .06 & .22 & .15 & .51 \\
SWE & .09 & .01 & .07 & .03 & .17 \\
\hline Sol &.$B a r$ & & 09 & \\
\hline
\end{tabular}

Source: 'Barriers to entrepreneurship' is sourced from the OECD Regulatory database.

The Herfindahl Index is based on author's calculations using the Amadeus database.

\section{Empirical analysis of firm-level productivity}

\subsection{The effect of competition}

Competition may stem from both foreign as well as domestic sources, which we take into account by differentiating the two. Our methodology assumes that increased import shares are equivalent to an increase in competition within a narrowly defined industry and that this 
increase is exogenous to the productivity growth of an individual firm. Several studies document that increased imports amount to tougher competition: for instance, Katics and Petersen (1994) find that it is associated with reduced price-cost margins using industry-level data for the United States. Recent empirical studies, including Aghion et al. (2009), Bas and Strauss-Kahn (2011), Fernandez (2007) and Pavnick (2002), use import shares as measures of competition from trade, while Kletzer (2002) discusses assumptions necessary for this approach to be valid. Using a more structural approach, Chen et al. (2009) find that import penetration has a boosting effect on industry average productivity, supporting the pro-competitive effect of trade predicted by the theoretical model of Melitz and Ottaviano (2008).

To capture domestic competition, different measures have been proposed in the literature, such as price-cost margins and concentration indexes. Both measures have substantial flaws. First, they do not allow the effect of foreign competition to be distinguished from the effect of domestic competition. Secondly, while both sources of competition are supposed to put a downward pressure on price-cost margins, it is not clear that higher concentration indexes indicate lower competitive forces. Indeed, pressures from abroad may lead to exit of domestic firms, resulting in a small number of national firms operating, and a more concentrated domestic sector. While we control for concentration, we believe that the two sub-indexes of product market regulation that we use, namely barriers to entrepreneurship and burdens on startups, capture more accurately domestic competitive pressures, as they are direct measures of barriers to market entry.

Aghion et al. (2009) exploit several policy reforms that influenced the competitive environment in Europe, namely the European Single Market Program and industry specific reforms imposed by the Monopolies and Mergers Commission. They claim that those experiments enable them to identify the causal impact of competition on innovation. The perspective of this paper is similar; it makes the most of a country-specific product market regulation (PMR) index that captures various product market reforms that took place in OECD countries between 1998 and 2008. The product market regulation index captures various policies with different treatment intensity across countries and time.

Our empirical analysis highlights that the effect of foreign competition varies with the local stringency of product market regulation. Theoretical predictions on the interaction between trade and product market regulation are ambiguous though. On one hand, PMR and openness can go in the same direction and have a positive additive effect by demanding further productiv- 
ity improvements. While foreign exposure reduces rents and demand stronger competitiveness to survive, this pro-competitive effect can be higher in countries with stringent regulation protecting incumbents as it creates new incentives to upgrade the production technology. On the other hand, rigidities can impede reallocation, innovation and firm adjustments, reducing the ability to react quickly to new competitive pressures.

We contribute to the literature trying to answer this question by estimating productivity growth equations at the firm level where exposure to international markets and to domestic regulation both interact. We find that their effect can be non-linear and depends on the characteristics of heterogeneous firms, especially their distance to the global technological frontier.

\subsection{Empirical specification: difference-in-differences}

We relate firm TFP growth to domestic and foreign competition in the following way:

$$
\Delta A_{i s c t}=\beta_{0}+\beta_{1} I P_{s c t}+\beta_{2} I P_{s c t} \times P M R_{c t}+\beta_{3} X_{i s c t}+\gamma_{s}+D_{c t}+\epsilon_{i s c t}
$$

where $\Delta A_{\text {isct }}$ is the productivity growth of firm $i$ that belongs to sector $s$ and country $c, I P_{s c t}$ is the level of import penetration in sector $s$ for country $c$ in year $t, P M R_{c t}$ is the level of product market regulation in country $c$ and year $t$. One issue is that productivity growth can vary across firms because of sectoral features that have nothing to do with competitive pressures. To avoid any spurious correlation due to industry characteristics, sector fixed effects $\gamma_{s}$ are included. They capture time-invariant characteristics that, for example, shape the potential for technological upgrading. It is also very likely that TFP growth is influenced by other institutional determinants or policies that do not affect competition. Country-time fixed effects $D_{c t}$ are added to deal with this type of correlation. The country-time fixed effects also address country macroeconomic shock common to all sectors. $X_{i s c t}$ is a set of control variables that vary across firms and time such as the size of the firm or across sectors $s$, country $c$ and time $t$ such as the level of concentration or the impact of regulation in services sectors on the manufacturing sector under study.

Equation 6 enables us to understand first how firm TFP growth depends on foreign competition $\left(\beta_{1}\right)$, second, how the effect of foreign competition varies with the regulation of the product market $\left(\beta_{2}\right)$. Since we control for industry and country-time fixed effects, this specification identifies the effect of foreign competition through differential evolution of the import 
penetration across industries (industry-time variation).

Models of endogenous growth, considering the existence of technological flows between firms across all countries, dwell on the role played by the pool of highly innovative firms in driving productivity growth of incumbent firms. Productivity growth of followers depends on the productivity growth of the world technological frontier. Adding productivity growth of the frontier firms (top 1 percent), we estimate:

$$
\Delta A_{i s c t}=\beta_{0}+\Delta A_{s t}^{\text {front }}+\beta_{1} I P_{s c t}+\beta_{2} I P_{s c t} \times P M R_{c t}+\beta_{3} X_{i s c t}+\gamma_{s}+D_{c t}+\epsilon_{i s c t}
$$

where $\Delta A_{s t}^{\text {front }}$ is the frontier's productivity growth. We compute the productivity level of the industry-year specific frontier $A_{s t}^{\text {front }}$ by taking the average productivity of the top 1 percent of firms across all countries: it is thus a global frontier which is consistent with our cross-country empirical strategy 4

\subsection{The importance of the firm's distance to the frontier}

We allow for a non-monotonic effect of competition according to the heterogeneity of firms. We consider their position on the productivity distribution specific to their industry, the right tail of the distribution representing the productivity frontier. Is the positive escape-competition effect conditional on the distance of the firm to its industry frontier? The rationale behind this question is the following: the closer firms are to the frontier, the stronger the escape-competition effect on TFP growth tends to be. In other words, the pro-competitive effect of trade displays a boosting effect for firms with relatively high level of productivity. On the other hand, for laggard firms, an increase of competition due to the entry of foreign products on their market has a depressing effect because they are too far from the frontier to cope with it.

To capture the size of the technology gap among firms in an open-economy setting, we compare each firm's productivity to the median productivity of the the same sector and year. We then divide firms into two groups: a group of firms that are above the median level of TFP - those closer to the global TFP frontier - and a group of firms that have a TFP level below the median of their industry - who have a larger technological gap. To evaluate the differential impact of foreign competition and product market regulation according to firm heterogeneity in technology gap, we estimate Equations 6 and 7 separately for the two sub-samples.

\footnotetext{
${ }^{4}$ As a robustness check, we also compute the productivity frontier using the average of the top $5 \%$ of firms.
} 
Table 4: Contemporaneous impact of import penetration and PMR on firms' TFP growth

Not resampled data set

\begin{tabular}{|c|c|c|c|c|c|c|}
\hline \multirow[t]{3}{*}{ PMR variable } & \multicolumn{6}{|c|}{ BARRIERS TO ENTREPRENEURSHIP } \\
\hline & $(1)$ & $(2)$ & $(3)$ & $(4)$ & $(5)$ & $(6)$ \\
\hline & $\begin{array}{c}\text { All } \\
\text { firms }\end{array}$ & $\begin{array}{l}\text { Close to } \\
\text { the frontier }\end{array}$ & $\begin{array}{l}\text { Far from } \\
\text { the frontier }\end{array}$ & $\begin{array}{c}\text { All } \\
\text { firms }\end{array}$ & $\begin{array}{l}\text { Close to } \\
\text { the frontier }\end{array}$ & $\begin{array}{l}\text { Far from } \\
\text { the frontier }\end{array}$ \\
\hline \multirow[t]{2}{*}{ IP } & $0.202^{* *}$ & $0.555^{* *}$ & -0.037 & $0.191^{* *}$ & $0.453^{* *}$ & 0.005 \\
\hline & $(0.094)$ & $(0.215)$ & $(0.063)$ & $(0.090)$ & $(0.223)$ & $(0.055)$ \\
\hline \multirow[t]{2}{*}{$\mathrm{IP} \times \mathrm{PMR}$} & $-0.107^{* *}$ & $-0.297 * * *$ & 0.018 & $-0.118^{* *}$ & $-0.288^{* *}$ & 0.044 \\
\hline & $(0.048)$ & $(0.115)$ & $(0.032)$ & $(0.052)$ & $(0.114)$ & $(0.035)$ \\
\hline \multirow[t]{2}{*}{ Herf } & & & & -0.149 & -0.164 & $0.326^{* * *}$ \\
\hline & & & & $(0.260)$ & $(0.388)$ & $(0.097)$ \\
\hline \multirow{2}{*}{$\mathrm{IP} \times$ Herf } & & & & 0.063 & 0.196 & $-0.161^{* * *}$ \\
\hline & & & & $(0.057)$ & $(0.148)$ & $(0.061)$ \\
\hline \multirow[t]{2}{*}{ Constant } & -0.069 & 0.240 & $-0.384^{* * *}$ & -0.029 & 0.295 & $-0.464^{* * *}$ \\
\hline & $(0.311)$ & $(0.389)$ & $(0.062)$ & $(0.322)$ & $(0.406)$ & $(0.069)$ \\
\hline Observations & 417,139 & 213,970 & 203,169 & 417,139 & 213,970 & 203,169 \\
\hline R-squared & 0.025 & 0.034 & 0.031 & 0.025 & 0.034 & 0.031 \\
\hline Sector FE & Yes & Yes & Yes & Yes & Yes & Yes \\
\hline Country-Year FE & Yes & Yes & Yes & Yes & Yes & Yes \\
\hline
\end{tabular}

\subsection{The issue of reverse causality}

Foreign competition is proxied by import penetration. It is possible that a bias exists because of reverse causality between productivity and trade orientation. Foreign firms are able to enter more heavily a market if domestic firms are not efficient, leaving the competitive advantage to trade partners. This implies a negative correlation between productivity and import shares. However, this relation should be weak in our specification as we regress firm level productivity on sectoral import shares. We also consider that the reverse causality issue is less acute when we look at TFP growth compared to productivity levels. Finally, this could bias us away from finding a productivity enhancing effect of import competition. In spite of it, our results indicate a positive relationship between productivity growth of the top firms and import penetration, which strongly strengthen our confidence in such a finding.

\subsection{Interpretation of results}

The first set of results of the estimation of equation 6 are shown in Tables 4 and 5, while Tables 6, 7 and 8 provide robustness checks of the same equation. These results are based on the regression of firm-level productivity growth on import penetration $(I P)$ and the interaction between import penetration and domestic regulation $(I P \times P M R)$. Import penetration at 
Table 5: Lagged impact of import penetration and PMR on firms' TFP growth

Not resampled data set

\begin{tabular}{|c|c|c|c|c|c|c|}
\hline \multirow[t]{3}{*}{ PMR variable } & \multicolumn{6}{|c|}{ BARRIERS TO ENTREPRENEURSHIP } \\
\hline & $(1)$ & $(2)$ & $(3)$ & $(4)$ & (5) & $(6)$ \\
\hline & $\begin{array}{l}\text { All } \\
\text { firms }\end{array}$ & $\begin{array}{l}\text { Close to } \\
\text { the frontier }\end{array}$ & $\begin{array}{l}\text { Far from } \\
\text { the frontier }\end{array}$ & $\begin{array}{l}\text { All } \\
\text { firms }\end{array}$ & $\begin{array}{l}\text { Close to } \\
\text { the frontier }\end{array}$ & $\begin{array}{l}\text { Far from } \\
\text { the frontier }\end{array}$ \\
\hline \multirow{2}{*}{$\mathrm{IP}_{t-1}$} & $0.166^{*}$ & $0.518^{* *}$ & -0.039 & 0.135 & $0.419^{*}$ & -0.012 \\
\hline & $(0.100)$ & $(0.222)$ & $(0.071)$ & $(0.096)$ & $(0.249)$ & $(0.071)$ \\
\hline \multirow[t]{2}{*}{$\mathrm{IP} \times \mathrm{PMR}_{t-1}$} & $-0.088^{*}$ & $-0.281^{* *}$ & 0.025 & $-0.108^{* *}$ & $-0.268^{* *}$ & 0.036 \\
\hline & $(0.051)$ & $(0.118)$ & $(0.034)$ & $(0.052)$ & $(0.120)$ & $(0.037)$ \\
\hline \multirow[t]{2}{*}{ Herf $_{t-1}$} & & & & -0.046 & 0.042 & $0.314^{* * *}$ \\
\hline & & & & $(0.230)$ & $(0.408)$ & $(0.088)$ \\
\hline \multirow[t]{2}{*}{$\mathrm{IP} \times \operatorname{Herf}_{t-1}$} & & & & $0.142^{* *}$ & 0.168 & -0.089 \\
\hline & & & & $(0.057)$ & $(0.142)$ & $(0.068)$ \\
\hline \multirow[t]{2}{*}{ Constant } & 0.380 & 0.908 & $-0.428^{* * *}$ & 0.408 & 0.907 & $-0.489^{* * *}$ \\
\hline & $(0.731)$ & $(0.942)$ & $(0.088)$ & $(0.731)$ & $(0.940)$ & $(0.093)$ \\
\hline Observations & 454,375 & 233,529 & 220,846 & 454,375 & 233,529 & 220,846 \\
\hline R-squared & 0.022 & 0.030 & 0.033 & 0.022 & 0.030 & 0.033 \\
\hline Sector FE & Yes & Yes & Yes & Yes & Yes & Yes \\
\hline Country-Year FE & Yes & Yes & Yes & Yes & Yes & Yes \\
\hline
\end{tabular}

the sectoral level $(I P)$ is used to proxy foreign competition pressures, while the 'barriers to entrepreneurship' index is used to measure the stringency of domestic regulation $(P M R)$. The same equations are also estimated with the control variables. The first set of results, Tables 4 through 7, use the 'barriers to entrepreneurship' index (PMR) contemporaneously and with lags, both with the default dataset (Tables 4 and 5) and the resampled dataset (Tables 6 and 7).

Overall, the results, which split the sample by distance to frontier, are highly consistent with our hypotheses, and are robust across specifications, including those that account for potential reverse causality (using lagged values of $I P$ ) and potential sampling bias (on the resampled dataset).

Changes in firm productivity are impacted by both the domestic institutional environment and the extent of openness to foreign markets. However, firms' responses to foreign competition are heterogeneous, even within narrowly defined sectors. The evolution of firm TFP growth depends remarkably on its position in the distribution of firm efficiency. Firms that are technologically advanced benefit from competitive pressure of foreign firms' entry into their domestic markets. This "escape competition effect" is only present for the most competitive firms, with foreign competition generally having no significant impact on firms that are at the bottom of the efficiency distribution. 
Table 6: Contemporaneous impact of import penetration and PMR on firms' TFP growth

Resampled data set

\begin{tabular}{|c|c|c|c|c|c|c|}
\hline \multirow[t]{3}{*}{ PMR variable } & \multicolumn{6}{|c|}{ BARRIERS TO ENTREPRENEURSHIP } \\
\hline & $(1)$ & $(2)$ & $(3)$ & $(4)$ & $(5)$ & $(6)$ \\
\hline & $\begin{array}{l}\text { All } \\
\text { firms }\end{array}$ & $\begin{array}{l}\text { Close to } \\
\text { the frontier }\end{array}$ & $\begin{array}{l}\text { Far from } \\
\text { the frontier }\end{array}$ & $\begin{array}{l}\text { All } \\
\text { firms }\end{array}$ & $\begin{array}{l}\text { Close to } \\
\text { the frontier }\end{array}$ & $\begin{array}{l}\text { Far from } \\
\text { the frontier }\end{array}$ \\
\hline \multirow[t]{2}{*}{ IP } & -0.020 & $0.427^{* *}$ & -0.023 & -0.005 & $0.409^{*}$ & -0.002 \\
\hline & $(0.204)$ & $(0.213)$ & $(0.075)$ & $(0.207)$ & $(0.213)$ & $(0.080)$ \\
\hline \multirow[t]{2}{*}{$\mathrm{IP} \times \mathrm{PMR}$} & 0.007 & $-0.232^{* *}$ & 0.008 & 0.002 & $-0.234^{* *}$ & 0.009 \\
\hline & $(0.105)$ & $(0.114)$ & $(0.037)$ & $(0.105)$ & $(0.115)$ & $(0.039)$ \\
\hline \multirow[t]{2}{*}{ Herf } & & & & 0.371 & 0.303 & 0.117 \\
\hline & & & & $(0.252)$ & $(0.304)$ & $(0.097)$ \\
\hline \multirow[t]{2}{*}{$\mathrm{IP} \times$ Herf } & & & & -0.010 & 0.036 & -0.049 \\
\hline & & & & $(0.043)$ & $(0.079)$ & $(0.046)$ \\
\hline \multirow[t]{2}{*}{ Constant } & $-0.179 *$ & $-5.055^{* * *}$ & $0.073^{* *}$ & $-0.295^{* *}$ & $-5.174^{* * *}$ & 0.042 \\
\hline & $(0.100)$ & $(0.960)$ & $(0.029)$ & $(0.150)$ & $(0.991)$ & $(0.039)$ \\
\hline Observations & 348,007 & 162,479 & 164,429 & 348,007 & 162,479 & 164,429 \\
\hline R-squared & 0.037 & 0.043 & 0.025 & 0.037 & 0.043 & 0.025 \\
\hline Sector FE & Yes & Yes & Yes & Yes & Yes & Yes \\
\hline Country-Year FE & Yes & Yes & Yes & Yes & Yes & Yes \\
\hline
\end{tabular}

Robust standard errors in parentheses, clustered standard errors by country and sector.

$* * * \mathrm{p}<0.01, * * \mathrm{p}<0.05, * \mathrm{p}<0.1$

Table 7: Lagged impact of import penetration and PMR on firms' TFP growth

Resampled data set

\begin{tabular}{|c|c|c|c|c|c|c|}
\hline \multirow[t]{3}{*}{ PMR variable } & \multicolumn{6}{|c|}{ BARRIERS TO ENTREPRENEURSHIP } \\
\hline & $(1)$ & $(2)$ & (3) & $(4)$ & $(5)$ & (6) \\
\hline & $\begin{array}{l}\text { All } \\
\text { firms }\end{array}$ & $\begin{array}{l}\text { Close to } \\
\text { the frontier }\end{array}$ & $\begin{array}{l}\text { Far from } \\
\text { the frontier }\end{array}$ & $\begin{array}{l}\text { All } \\
\text { firms }\end{array}$ & $\begin{array}{l}\text { Close to } \\
\text { the frontier }\end{array}$ & $\begin{array}{l}\text { Far from } \\
\text { the frontier }\end{array}$ \\
\hline $\mathrm{IP}_{t-1}$ & $\begin{array}{c}0.422^{* *} \\
(0.209)\end{array}$ & $\begin{array}{c}0.718^{* *} \\
(0.282)\end{array}$ & $\begin{array}{l}0.273^{*} \\
(0.160)\end{array}$ & $\begin{array}{c}0.400^{*} \\
(0.228)\end{array}$ & $\begin{array}{c}0.645^{* *} \\
(0.305)\end{array}$ & $\begin{array}{c}0.339 * * \\
(0.159)\end{array}$ \\
\hline $\mathrm{IP} \times \mathrm{PMR}_{t-1}$ & $\begin{array}{l}-0.193^{*} \\
(0.099)\end{array}$ & $\begin{array}{c}-0.357^{* * *} \\
(0.134)\end{array}$ & $\begin{array}{l}-0.128^{*} \\
(0.076)\end{array}$ & $\begin{array}{l}-0.193^{*} \\
(0.099)\end{array}$ & $\begin{array}{c}-0.348^{* *} \\
(0.135)\end{array}$ & $\begin{array}{l}-0.127^{*} \\
(0.076)\end{array}$ \\
\hline $\operatorname{Herf}_{t-1}$ & & & & $\begin{array}{l}-0.024 \\
(0.288)\end{array}$ & $\begin{array}{c}-0.249 \\
(0.351)\end{array}$ & $\begin{array}{c}0.067 \\
(0.110)\end{array}$ \\
\hline $\mathrm{IP} \times \operatorname{Herf}_{t-1}$ & & & & $\begin{array}{c}0.051 \\
(0.208)\end{array}$ & $\begin{array}{c}0.302 \\
(0.304)\end{array}$ & $\begin{array}{l}-0.160 \\
(0.105)\end{array}$ \\
\hline Constant & $\begin{array}{c}-0.250^{* * *} \\
(0.062)\end{array}$ & $\begin{array}{c}-5.269^{* * *} \\
(0.832)\end{array}$ & $\begin{array}{c}-0.089^{* * *} \\
(0.018)\end{array}$ & $\begin{array}{c}-0.241^{* *} \\
(0.115)\end{array}$ & $\begin{array}{c}-5.189^{* * *} \\
(0.854)\end{array}$ & $\begin{array}{c}-0.117^{* * *} \\
(0.035)\end{array}$ \\
\hline Observations & 338,137 & 158,549 & 159,645 & 338,137 & 158,549 & 159,645 \\
\hline R-squared & 0.039 & 0.043 & 0.028 & 0.039 & 0.043 & 0.028 \\
\hline Sector FE & Yes & Yes & Yes & Yes & Yes & Yes \\
\hline Country-Year FE & Yes & Yes & Yes & Yes & Yes & Yes \\
\hline
\end{tabular}

Robust standard errors in parentheses, clustered standard errors by country and sector.

*** $\mathrm{p}<0.01,{ }^{*} * \mathrm{p}<0.05, * \mathrm{p}<0.1$ 
Table 8: The impact of import penetration and PMR on firms' TFP growth

Not resampled data set

\begin{tabular}{|c|c|c|c|c|c|c|}
\hline \multirow[t]{3}{*}{ PMR variable } & \multicolumn{6}{|c|}{ BURDENS ON STARTUPS } \\
\hline & $(1)$ & $(2)$ & $(3)$ & $(4)$ & $(5)$ & (6) \\
\hline & $\begin{array}{l}\text { All } \\
\text { firms }\end{array}$ & $\begin{array}{l}\text { Close to } \\
\text { the frontier }\end{array}$ & $\begin{array}{l}\text { Far from } \\
\text { the frontier }\end{array}$ & $\begin{array}{l}\text { All } \\
\text { firms }\end{array}$ & $\begin{array}{l}\text { Close to } \\
\text { the frontier }\end{array}$ & $\begin{array}{l}\text { Far from } \\
\text { the frontier }\end{array}$ \\
\hline \multirow[t]{2}{*}{ IP } & 0.075 & $0.189^{* * *}$ & $-0.039 *$ & $0.181^{* *}$ & 0.122 & 0.071 \\
\hline & $(0.050)$ & $(0.073)$ & $(0.023)$ & $(0.072)$ & $(0.113)$ & $(0.070)$ \\
\hline \multirow[t]{2}{*}{$\mathrm{IP} \times \mathrm{PMR}$} & $-0.055^{*}$ & $-0.117^{* * *}$ & $0.032^{*}$ & $-0.079^{* * *}$ & $-0.113^{* *}$ & 0.012 \\
\hline & $(0.029)$ & $(0.044)$ & $(0.019)$ & $(0.029)$ & $(0.044)$ & $(0.025)$ \\
\hline \multirow[t]{2}{*}{ Herf } & & & & -0.121 & -0.035 & $0.422^{* * *}$ \\
\hline & & & & $(0.260)$ & $(0.277)$ & $(0.101)$ \\
\hline \multirow[t]{2}{*}{$\mathrm{IP} \times$ Herf } & & & & -0.141 & 0.130 & $-0.145^{*}$ \\
\hline & & & & $(0.086)$ & $(0.159)$ & $(0.078)$ \\
\hline \multirow[t]{2}{*}{ Constant } & -0.042 & -0.614 & $-0.481 * * *$ & -0.017 & -0.597 & $-0.561^{* * *}$ \\
\hline & $(0.309)$ & $(0.470)$ & $(0.109)$ & $(0.323)$ & $(0.475)$ & $(0.104)$ \\
\hline Observations & 417,389 & 237,355 & 160,651 & 417,389 & 237,355 & 160,651 \\
\hline R-squared & 0.025 & 0.046 & 0.035 & 0.025 & 0.046 & 0.035 \\
\hline Sector FE & Yes & Yes & Yes & Yes & Yes & Yes \\
\hline Country-Year FE & Yes & Yes & Yes & Yes & Yes & Yes \\
\hline
\end{tabular}

The positive pro-competitive effect of trade on advanced firms has a different magnitude according to the extent of product market regulation in the country. The negative coefficient on the interaction term indicates that trade becomes more beneficial as market regulation becomes less stringent. The 'barriers to entrepreneurship' PMR index is used in the estimates shown in Tables 4, 5, 6 and 7, which reflects anti-competitive measures such as entry barriers and administrative burdens that inhibit competition across sectors.

To more clearly delineate the effects of the measures, the 'burdens on startups' sub-indicator is used in Table 8. This indicator focuses more clearly on administrative burdens for new firms, including sector-specific burdens. Using this index, these results yield coefficient estimates that are qualitatively very similar to the estimates with the broader PMR 'barriers to entrepreneurship' index shown in the previous tables. The other two PMR sub-indicators of this index, 'regulatory and administrative opacity' and 'barriers to competition', show less significance.

Domestic competition may also vary within a country, across sectors. This may have an effect on firms' incentives to upgrade their technology. The level of competition within a sector can be proxied by the concentration level within a sector ${ }^{5}$ In concentrated sectors, firms are

\footnotetext{
${ }^{5}$ We also use the Regimpact regulatory impact index to help control for pressures that may affect costs. Regimpact can control for the cost structure of intermediate inputs coming from upstream sectors. Robustness checks were run with all of the estimated equations, and the inclusion of Regimpact in the equations does not affect the interpretation of the estimates. Firms that are closer to the frontier are found to cope more easily with
} 
Table 9: The impact of IP and PMR on firms' TFP growth, with frontier TFP growth

Not resampled data set

\begin{tabular}{|c|c|c|c|c|c|c|}
\hline \multirow[t]{3}{*}{ PMR variable } & \multicolumn{6}{|c|}{ BARRIERS TO ENTREPRENEURSHIP } \\
\hline & $(1)$ & $(2)$ & $(3)$ & (4) & (5) & (6) \\
\hline & $\begin{array}{c}\text { All } \\
\text { firms }\end{array}$ & $\begin{array}{l}\text { Close to } \\
\text { the frontier }\end{array}$ & $\begin{array}{l}\text { Far from } \\
\text { the frontier }\end{array}$ & $\begin{array}{c}\text { All } \\
\text { firms }\end{array}$ & $\begin{array}{l}\text { Close to } \\
\text { the frontier }\end{array}$ & $\begin{array}{l}\text { Far from } \\
\text { the frontier }\end{array}$ \\
\hline \multirow[t]{2}{*}{$\Delta A^{\text {front }}$} & $0.003^{* * *}$ & $0.005^{* *}$ & $0.001^{*}$ & $0.003^{* * *}$ & $0.005^{* *}$ & $0.001^{*}$ \\
\hline & $(0.001)$ & $(0.002)$ & $(0.001)$ & $(0.001)$ & $(0.002)$ & $(0.001)$ \\
\hline \multirow[t]{2}{*}{ IP } & $0.172^{* *}$ & $0.494^{* *}$ & -0.040 & $0.162^{*}$ & $0.382^{*}$ & 0.002 \\
\hline & $(0.087)$ & $(0.197)$ & $(0.063)$ & $(0.086)$ & $(0.202)$ & $(0.055)$ \\
\hline \multirow[t]{2}{*}{$\mathrm{IP} \times \mathrm{PMR}$} & $-0.092^{* *}$ & $-0.265^{* *}$ & 0.020 & $-0.102^{* *}$ & $-0.252^{* *}$ & 0.046 \\
\hline & $(0.045)$ & $(0.105)$ & $(0.032)$ & $(0.050)$ & $(0.104)$ & $(0.035)$ \\
\hline \multirow[t]{2}{*}{ Herf } & & & & 0.160 & 0.239 & $0.346^{* * *}$ \\
\hline & & & & $(0.191)$ & $(0.374)$ & $(0.097)$ \\
\hline \multirow[t]{2}{*}{$\mathrm{IP} \times$ Herf } & & & & 0.058 & 0.204 & $-0.164^{* * *}$ \\
\hline & & & & $(0.055)$ & $(0.143)$ & $(0.061)$ \\
\hline \multirow[t]{2}{*}{ Constant } & $-0.612^{* * *}$ & $-0.770^{* *}$ & $-0.425^{* * *}$ & $-0.637^{* * *}$ & $-0.817^{* *}$ & $-0.503^{* * *}$ \\
\hline & $(0.191)$ & $(0.350)$ & $(0.092)$ & $(0.206)$ & $(0.393)$ & $(0.102)$ \\
\hline Observations & 414,890 & 211,820 & 203,070 & 414,890 & 211,820 & 203,070 \\
\hline R-squared & 0.032 & 0.042 & 0.031 & 0.032 & 0.043 & 0.031 \\
\hline Sector FE & Yes & Yes & Yes & Yes & Yes & Yes \\
\hline Country-Year FE & Yes & Yes & Yes & Yes & Yes & Yes \\
\hline
\end{tabular}

not forced to reduce prices and can make positive profits more easily. Hence low productivity firms can survive. Our analysis suggests that the concentration level has a different impact on more advanced versus laggard firms, based on the raw dataset (Tables 4 and 5). While high concentration seems to allow less efficient firms to perform well, it is not a condition for high productivity firms whose TFP growth rates are not significantly affected by the concentration level. Such a concentration index is however an imperfect measure of competition as it does not capture the existence of entry threats. Moreover it focuses on a geographically limited definition of competition while European manufacturing sectors are open and some firms operate in international markets. Our favored measure of competition is the product market regulation index, as it can proxy unobservable entry threats as well as the existing regulatory scope that can be used to adjust to changes in market structure.

These results are robust to a number of alternative specifications, such as inclusion of the growth of the productivity frontier (Table 9, using equation 7 ) or the restriction of the sample to surviving firms only (Table 10). While these changes in specification have a slight impact on the results, they remain the same in sign, significance and roughly the same in magnitude,

high regulation in upstream services sectors, and it has a damping effect on firms farther from the frontier. 
Table 10: The impact of IP and PMR on surviving firms' TFP growth

Not resampled, balanced data set

\begin{tabular}{|c|c|c|c|c|c|c|}
\hline \multirow[t]{3}{*}{ PMR variable } & \multicolumn{6}{|c|}{ BARRIERS TO ENTREPRENEURSHIP } \\
\hline & $(1)$ & (2) & (3) & (4) & (5) & (6) \\
\hline & $\begin{array}{c}\text { All } \\
\text { firms }\end{array}$ & $\begin{array}{l}\text { Close to } \\
\text { the frontier }\end{array}$ & $\begin{array}{l}\text { Far from } \\
\text { the frontier }\end{array}$ & $\begin{array}{c}\text { All } \\
\text { firms }\end{array}$ & $\begin{array}{l}\text { Close to } \\
\text { the frontier }\end{array}$ & $\begin{array}{l}\text { Far from } \\
\text { the frontier }\end{array}$ \\
\hline \multirow[t]{2}{*}{ IP } & $0.212^{* *}$ & $0.602^{* * *}$ & -0.024 & $0.199^{*}$ & $0.571^{* * *}$ & 0.032 \\
\hline & $(0.106)$ & $(0.218)$ & $(0.075)$ & $(0.101)$ & $(0.216)$ & $(0.069)$ \\
\hline \multirow[t]{2}{*}{$\mathrm{IP} \times \mathrm{PMR}$} & $-0.114^{* *}$ & $-0.323^{* * *}$ & 0.014 & $-0.119^{* *}$ & $-0.319 * * *$ & 0.036 \\
\hline & $(0.056)$ & $(0.116)$ & $(0.038)$ & $(0.057)$ & $(0.115)$ & $(0.041)$ \\
\hline \multirow[t]{2}{*}{ Herf } & & & & -0.021 & 0.019 & $0.384^{* * *}$ \\
\hline & & & & $(0.268)$ & $(0.441)$ & $(0.120)$ \\
\hline \multirow[t]{2}{*}{ IP $\times$ Herf } & & & & 0.048 & 0.056 & $-0.187^{* *}$ \\
\hline & & & & $(0.065)$ & $(0.111)$ & $(0.077)$ \\
\hline \multirow[t]{2}{*}{ Constant } & $-0.688^{*}$ & -0.945 & $-0.429 * * *$ & $-0.677^{*}$ & -0.944 & $-0.525^{* * *}$ \\
\hline & $(0.380)$ & $(0.649)$ & $(0.043)$ & $(0.382)$ & $(0.657)$ & $(0.050)$ \\
\hline Observations & 230,267 & 125,647 & 104,620 & 230,267 & 125,647 & 104,620 \\
\hline Sector FE & Yes & Yes & Yes & Yes & Yes & Yes \\
\hline Country-Year FE & Yes & Yes & Yes & Yes & Yes & Yes \\
\hline
\end{tabular}

in these contemporaneous results. We have also checked for the inclusion of other controls at the firm level, such as an indicator of exit during the period, the size of the firm, which has no discernible effect on the main results.

Inclusion of the direct effect of product market regulation has a somewhat larger effect on the results, which was expected as we include country fixed effect and year fixed effect separately to estimate the impact of country-wide PMR. Yet the results on our variables of principal interest, import penetration and its interaction with PMR remain qualitatively similar.

\subsection{Effects on productivity}

What is the economic significance of the results just discussed? Taking our preferred equation estimates from Table 4, the effects of changes in import penetration and product market reform can be simulated for within-firm productivity growth, among the relatively large firms in our dataset. Given the differences-in-differences specification of the estimation equation, we focus on conditional shocks. A qualitative visualisation of these simulations is shown in Figure 1.

Increases in import penetration (IP) only boost firm TFP growth if PMR is sufficiently low, below a certain threshold (Figure 1, Panel A) equivalent to the median PMR setting at the end of the period studied. If PMR is higher than this threshold, an increase in IP (i.e. international competition) has a perverse impact on TFP, leading to negative TFP growth 
Figure 1: Estimated within-firm TFP growth effects under conditional IP and PMR shocks

(a) Import penetration shocks: All firms

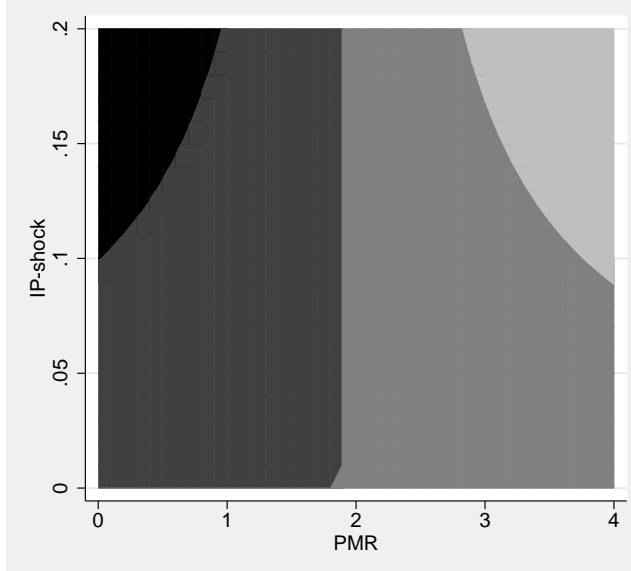

(c) Product market reform shocks: All firms

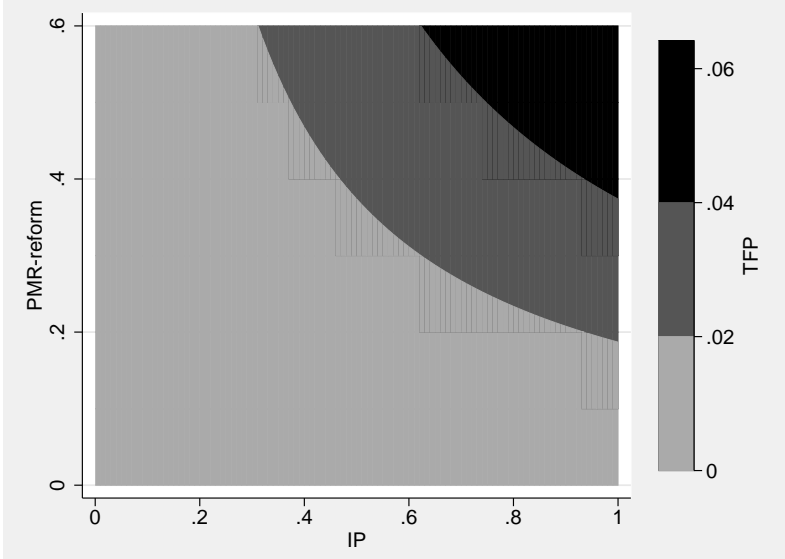

(b) IP shocks: Top firms

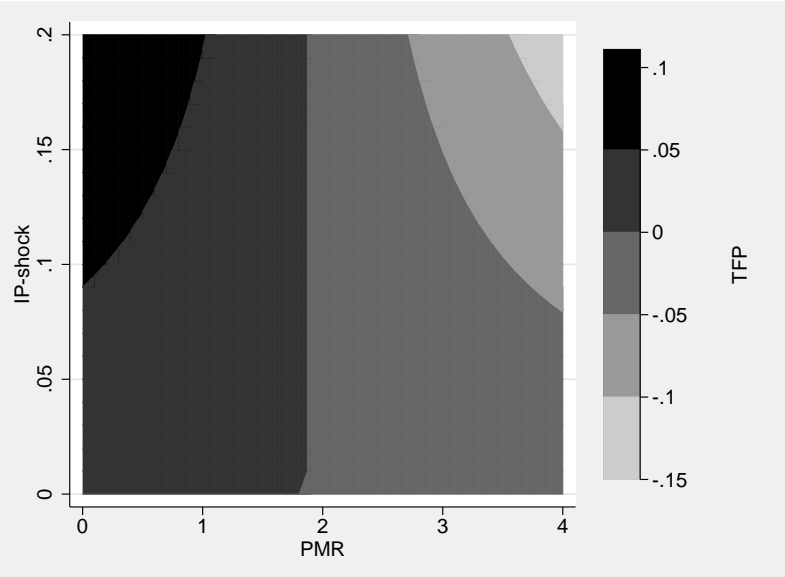

(d) PMR shocks: Top firms

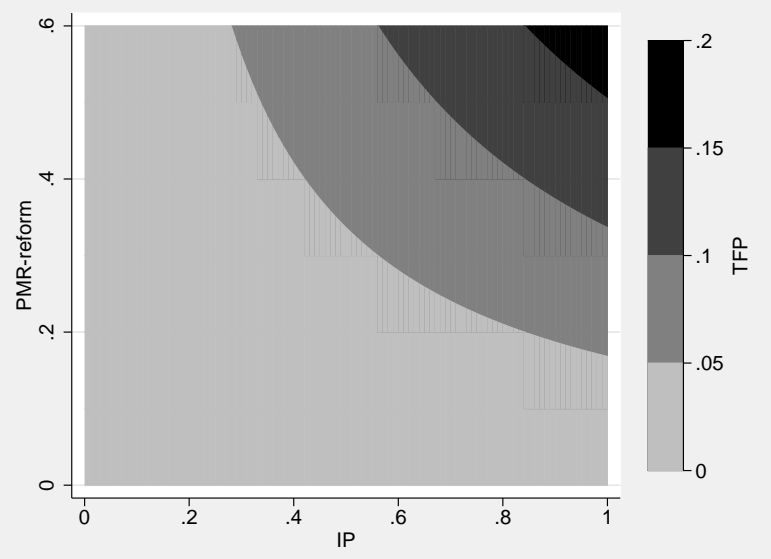

Source: Simulations based on equation estimates from Table 4, columns 2 and 3.

through discouragement. This effect arises from an even larger-magnitude effect on the firms in the upper half of the productivity distribution (Panel B). To take a particular example, for firms in the United Kingdom, the country with the lowest PMR, an increase in import penetration of 10 percentage points would raise firm TFP growth by approximately $1.0 \%$ per year on average, or $2.7 \%$ for the firms in the upper half of the productivity distribution. Yet for countries (primarily in earlier time periods) with higher PMR settings, the effect is essentially reversed.

A similar simulation can be carried out for a range of PMR reforms taking varying levels of import penetration as given (Figure 1, Panels C and D). Product market regulatory reforms unambiguously boost productivity growth; however, their effects are magnified considerably when import penetration is higher. For instance, a PMR reform of $10 \%$ of the median setting would boost within-firm productivity growth by $0.5 \%$ in a sector at the 25 th percentile of import 
penetration, and by $2.3 \%$ in a sector at the 75 th percentile. Again, the impact is driven by firms in the upper half of the productivity distribution, where productivity growth is boosted by $1.4 \%$ and $6.3 \%$, respectively. For firms in the lower half of the productivity distribution, the impact of PMR reform through this channel is negligible. Countries with a large share of high-productivity firms will thus benefit much more from PMR reforms.

\section{Conclusion}

This paper offers a new assessment of the effect of import penetration on firm-level productivity growth, taking into account heterogeneity in distance to the efficiency frontier and country differences in product market regulation. Our results show that firms in sectors with higher import penetration have higher TFP growth only if the firms are close to their sectoral technology frontier. Only the most productive firms enjoy an increase in productivity when foreign competitors' pressure is high. This result illustrates that in order to understand firms' TFP growth, it is important to combine explanations based on the pro-competitive effect of trade with a "Schumpeterian" distance to the frontier mechanism.

Further, this pro-competitive effect of international trade depends on domestic product market regulation as measured by the OECD's Product Market Regulation (PMR) index. Our results indicate that, at the top of the productivity distribution, the positive effect of foreign competition is inhibited for firms operating in a country with stringent regulation such as higher barriers to entry. Domestic and foreign competitive pressures are found to be complementarity: firms' incentives or abilities to improve their productivity to cope with foreign competition are stronger in countries with lower levels of PMR. As for firms at the bottom of the productivity distribution, foreign competition does not have a significant within-firm benefit on their efficiency - irrespective of the regulatory environment - though it may faciliate their demise, whereby they relinquish their market share to more productive firms. 


\section{References}

Acemoglu, D., P. Antràs and E. Helpman (2007), "Contracts and Technology Adoption", American Economic Review, Vol. 97, No. 3, pp. 916-943.

Aghion, P. and P. Howitt (2009), The Economics of Growth, MIT Press, Cambridge.

Aghion, P., R. Blundell, R. Griffith, P. Howitt and S. Prantl (2009), "The Effects of Entry on Incumbent Innovation and Productivity," The Review of Economics and Statistics, Vol. 91, No. 1, pp. 20-32.

Alcalá, F. and A. Ciccone (2004), "Trade and Productivity", Quarterly Journal of Economics, Vol. 119, No. 2, pp. 613-646.

Amiti, M. and J. Konings (2007), "Trade Liberalization, Intermediate Inputs, and Productivity: Evidence from Indonesia", American Economic Review, Vol. 97, No. 5, pp. 1611-38.

Arnold, J., G. Nicoletti, S. Scarpetta (2010), "Much ado about something? Regulation, resource reallocation and productivity in a panel of EU countries", Presented at the Ifo / CESifo \& OECD Conference on Regulation, January, www.oecd.org/dataoecd/20/37/44537865.pdf

Aw, B-Y, X-M Chen and M. Roberts (2001), "Firm-level Evidence on Productivity Differentials, Turnover, and Exports in Taiwanese Manufacturing", Journal of Development Economics, Vol. 66, No. 1, pp. 51-86.

Bartelsman, E., J. Haltiwanger and S. Scarpetta (2009), "Cross Country Differences in Productivity: The Role of Allocative Efficiency", NBER Working Papers, No. 15490, November.

Bas, M. and I. Ledezma (2010), "Trade Integration and Within-Plant Productivity Evolution in Chile," Review of World Economics, Vol. 146, No. 1, pp. 113-146.

Bas, M. and V. Strauss-Kahn (2011), "Does importing more inputs raise exports? Firm level evidence from France," CEPII Document du Travail, No. 2011-15, June.

Bernard, A., S. Redding, and P. Schott (2007), "Comparative Advantage and Heterogeneous Firms", Review of Economic Studies, Vol. 74, No. 1, pp. 31-66.

Bouët, A., Y. Decreux, L. Fontagné, S. Jean, D. Laborde (2008), "Assessing Applied Protection across the World", Review of International Economics, Vol. 16, No. 5, pp. 850-863.

Bourlès, R., G. Cette, J. Lopez, J. Mairesse, and G. Nicoletti (2010), "Do Product Market Regulations in Upstream Sectors Curb Productivity Growth? Panel Data Evidence for OECD Countries", NBER Working Papers, No. 16520, November.

Caves, D. W., L.R. Christensen and M.W. Tretheway (1980), "Flexible Cost Functions for Multiproduct Firms ", Review of Economics and Statistics, Vol. 62, No. 3, pp. 477-81.

Chen, N., J. Imbs, and A. Scott (2009), "The dynamics of trade and competition", Journal of International Economics, Vol. 77, No. 1, pp. 50-62. 
Conway, P., D. de Rosa, G. Nicoletti and F. Steiner (2006), "Product Market Regulation and Productivity Convergence", OECD Economic Studies, Vol. 43, No. 2, pp. 39-76.

Conway, P., S. Dougherty and A. Radziwill (2010), "Long-term growth and policy challenges in the large emerging economies", OECD Economics Dept. Working Papers, No. 755, March.

Dollar D. and A. Kraay (2003), "Institutions, trade, and growth", Journal of Monetary Economics, Vol. 50, No. 1, pp. 133-162.

Fernandez, A. (2007), "Trade policy, trade volumes and plant-level productivity in Colombian manufacturing industries", Journal of International Economics, Vol. 71, No. 1, pp. 52-71.

Foster, L., Haltiwanger, J. and C.J. Syverson (2008), "Market Selection, Reallocation, and Restructuring in the U.S. Retail Trade Sector in the 1990s", The Review of Economics and Statistics, Vol. 88, No. 4, pp. 748-758.

Freunda, C. and B. Bolakyb (2008), "Trade, regulations, and income", Journal of Development Economics, Vol. 87, No. 2, pp. 309-21.

Goldberg, P.K., A.K. Khandelwal, N. Pavcnik and P. Topalova (2010), "Imported Intermediate Inputs and Domestic Product Growth: Evidence from India", The Quarterly Journal of Economics, Vol. 125, No. 4, pp. 1727-67.

Katics, M. and B. Petersen (1994), "The Effect of Rising Import Competition on Market Power: A Panel Data Study of US Manufacturing", The Journal of Industrial Economics, Vol. 42, No. 3, pp. 277-286.

Kletzer, L. (2002), Imports, Exports and Jobs: What Does Trade Mean for Employment and Job Loss? W.E. Upjohn Institute for Employment Research, Kalamazoo, Michigan.

Levinsohn J. and A. Petrin (2003), "Estimating production functions using inputs to control for unobservables", Review of Economic Studies, Vol. 70, No. 2, pp. 317-341

Melitz, M. (2003), "The Impact of Trade on Intra-Industry Reallocations and Aggregate Industry Productivity", Econometrica, Vol. 71, No. 6, pp. 1695-1725.

Melitz, M. and G. Ottaviano (2008), "Market Size, Trade, and Productivity, Review of Economic Studies", Vol. 75, pp. 295-316.

Nicoletti, G. and S. Scarpetta (2003), "Regulation, Productivity and Growth: OECD Evidence," Economic Policy, Vol. 18, No. 36, pp. 9-72.

OECD (2003), The Sources of Growth in OECD Countries, OECD, Paris.

OECD (2006), Employment Outlook - Boosting Jobs and Incomes, OECD, Paris.

OECD (2011), Economic Policy Reforms: Going for Growth 2011, OECD, Paris, www.goingforgrowth.org. 
Olley, G.S. and A. Pakes (1996), "The Dynamics of Productivity in the Telecommunications Equipment Industry", Econometrica, Vol. 64, No. 6, pp. 1263-1297.

Pavcnik, N. (2002), "Trade Liberalization, Exit, and Productivity Improvement: Evidence from Chilean Plants", Review of Economic Studies, Vol. 69, No. 1, pp. 245-76.

Rodrick, D., A. Subramanian and F. Trebbi (2004), "Institutions Rule: The Primacy of Institutions over Geography and Integration in Economic Development", Journal of Economic Growth, Vol. 9, No. 2, pp. 271-303.

Schwellnus, C. and J. Arnold (2008), "Do Corporate Taxes Reduce Productivity and Investment at the Firm Level?: Cross-Country Evidence from the Amadeus Dataset", OECD Economics Department Working Papers, No. 641.

Topalova, P. (2004), "Trade Liberalization and Firm Productivity: The Case of India", IMF Working Papers, No. 04/28.

Wölfl, A., I. Wanner, T. Kozluk and G. Nicoletti (2009), "Ten Years of Product Market Reform in OECD Countries: Insights from a Revised PMR Indicator", OECD Economics Department Working Papers, No. 695. 


\section{WORKING PAPERS}

The full series of Economics Department Working Papers can be consulted at www.oecd.org/eco/workingpapers/

979 Non-Parametric Stochastic Simulations to Investigate Uncertainty around the OECD Indicator Model Forecasts

(August 2012) by Elena Rusticelli

978. $\quad$ Measuring GDP Forecast Uncertainty using Quantile Regressions

(July 2012) by Thomas Laurent and Tomasz Kozluk

977. Implications of output gap uncertainty in times of crisis

(July 2012) by Romain Bouis, Boris Cournède and Ane Kathrine Christensen

976. Avoiding debt traps: financial backstops and structural reforms

(July 2012) by Pier Carlo Padoan, Urban Sila and Paul van den Noord

975. Sluggish productivity growth in Denmark: the usual suspects?

(July 2012) by Müge Adalet McGowan and Stéphanie Jamet

974. Towards green growth in Denmark: improving energy and climate change policies

(July 2012) by Stéphanie Jamet

973. An Analysis of Productivity Performance in Spain before and during the Crisis: Exploring the Role of Institutions

(June 2012) Juan S. Mora-Sanguinetti and Andrés Fuentes

972. Europe's new fiscal rules

(June 2012) by Sebastian Barnes, David Davidsson and Lukasz Rawdanowicz

971. Credit Crises and the Shortcomings of Traditional Policy Responses

(June 2012) by William R. White

970. International Capital Mobility and Financial Fragility

Part 7. Enhancing Financial Stability: Country-specific Evidence on Financial Account and

Structural Policy Positions

(June 2012) by Rudiger Ahrend and Carla Valdivia

969. International Capital Mobility and Financial Fragility

Part 6. Are all Forms of Financial Integration Equally Risky in Times of Financial Turmoil? Asset

Price Contagion during the Global Financial Crisis

(June 2012) by Rudiger Ahrend and Antoine Goujard

968. International Capital Mobility and Financial Fragility

Part 5. Do Investors Disproportionately Shed Assets of Distant Countries under Increased

Uncertainty? Evidence from the Global Financial Crisis

(June 2012) by Rudiger Ahrend and Cyrille Schwellnus

967. International Capital Mobility and Financial Fragility

Part 4. Which Structural Policies Stabilise Capital Flows when Investors Suddenly Change their Mind? Evidence from Bilateral Bank Data 
(June 2012) by Rudiger Ahrend and Cyrille Schwellnus

966. International Capital Mobility and Financial Fragility

Part 3. How do Structural Policies affect Financial Crisis Risk? Evidence from Past Crises across OECD and Emerging Economies

(June 2012) by Rudiger Ahrend and Antoine Goujard

965. Sustaining Korea's convergence to the highest-income countries

(June 2012) by Randall S. Jones and Satoshi Urasawa

964. Achieving the "low carbon, green growth" vision in Korea

(June 2012) by Randall S. Jones and Byungseo Yoo

963. Promoting social cohesion in Korea

(June 2012) by Randall S. Jones and Satoshi Urasawa

962. Housing price and investment dynamics in Finland

(May 2012) by Christophe André and Clara Garcia

961. Improving health outcomes and system in Hungary

(May 2012) by Mehmet Eris

960. Towards a more inclusive labour market in Hungary

(May 2012) by Rafał Kierzenkowski

959. Ensuring stability and efficiency of the Hungarian financial sector

(May 2012) by Olena Havrylchyk

958. Ensuring debt sustainability amid strong economic uncertainty in Hungary

(June 2012) by Pierre Beynet and Rafał Kierzenkowski

957. Improving the health-care system in Poland

(April 2012) by Hervé Boulhol, Agnieszka Sowa and Stanislawa Golinowska

956. Options for benchmarking infrastructure performance

(April 2012) by Mauro Pisu, Peter Hoeller and Isabelle Joumard

955. Greenhouse gas emissions and price elasticities of transport fuel demand in Belgium

(April 2012) by Tom Schmitz

954. Bringing Belgian public finances to a sustainable path

(April 2012) by Tomasz Koźluk, Alain Jousten and Jens Høj

953. Climate change policies in Poland - minimising abatement costs

(April 2012) by Balázs Égert

952. Income inequality in the European Union

(April 2012) by Kaja Bonesmo Fredriksen

951. Reducing poverty in Chile: cash transfers and better jobs

(April 2012) by Nicola Brandt 